\title{
APPLICATION OF CLASSICAL LAND SURVEYING MEASUREMENT METHODS FOR DETERMINING THE VERTICAL DISPLACEMENT OF RAILWAY BRIDGES
}

\author{
Pelagia GAWRONEK ${ }^{1}$, Maria MAKUCH ${ }^{1}$ \\ University of Agriculture in Krakow, Kraków, Poland
}

\begin{abstract}
The classical measurements of stability of railway bridge, in the context of determining the vertical displacements of the object, consisted on precise leveling of girders and trigonometric leveling of controlled points (fixed into girders' surface). The construction elements, which were measured in two ways, in real terms belonged to the same vertical planes. Altitude measurements of construction were carried out during periodic structural stability tests and during static load tests of bridge by train. The specificity of displacement measurements, the type of measured object and the rail land surveying measurement conditions were determinants to define methodology of altitude measurement. The article presents compatibility of vertical displacements of steel railway bridge, which were developed in two measurement methods. In conclusion, the authors proposed the optimum concept of determining the vertical displacements of girders by using precise and trigonometric leveling (in terms of accuracy, safety and economy of measurement).
\end{abstract}

Keywords: displacement and deformation of structure, precise leveling, trigonometric leveling, steel railway bridge

\section{INTRODUCTION}

The discussion on the load-bearing capacity of railway bridges and the origins of formularizing the standards of safety of railway engineering structures began the construction disaster of a railway bridge over the Dee River in Chester in 1847.

${ }^{1}$ Corresponding author: University of Agriculture in Krakow, Department of Land Surveying, Balicka st 253A, 30-149 Kraków, Poland, p.gawronek@ur.krakow.pl, tel. +48126624539 
Investigating of the construction disaster of a railway bridge was the first one, which was conducted by the newly created Railway Inspectorate. The report on the causes of the construction disaster, made by Captain Simmons of the Royal Engineers - a leading researcher, stated that repeated vertical movements of steel girder of bridge weakened considerably its load-bearing capacity [22]. The railway bridge disaster in the south of England has become an inflammatory link in the dynamics research on railway bridge construction. The scientific results of research on the causes of the event, presented in 1849 by two pioneers in the field of mechanics of this type of construction - Willis and Stokes, showed that, the main cause of disaster was maximum deflection and distortion of the bridge loaded. More specifically, the cause of the construction disaster was not the dynamic load of the bridge during rail transport, but steel fatigue of structure [22]. The next decades brought technological development not only in the field of construction, but also railway. Research on the condition of railway infrastructure construction and its relationship with rail transport, launched in the mid of the $19^{\text {th }}$ century, provided the basis for formulating the first technical standards for the safety using of railway bridge. But, what is more, it should be emphasized that in the $1950^{\mathrm{s}}$ the operational speed of rail trains did not exceed $100 \mathrm{~km} \cdot \mathrm{h}^{-1}$. Today, freight trains do speeds of $160 \mathrm{~km} \cdot \mathrm{h}^{-1}$ and passenger trains do speeds of $350 \mathrm{~km} \cdot \mathrm{h}$ ${ }^{1}[10]$. The technological potential of trains must, however, be compatible with the load-bearing capacity of old railway infrastructure, and the standards for engineering stability should be kept up to date.

Currently, in Poland, sizeable proportion of railway bridges have reached the upper limit time for which they were designed. These objects, usually designed for a load less than the actual operational loads, are subject to accelerated degradation of the structure as a consequence of steel fatigue of structure. In the relatively lightweight structure of the steel bridge, the tautness which is caused by operating loads, has a significant share in the overall tautness of the structure [12]. The assumed (by PKP PKL S.A.) strength of steel railway bridges does not exceed 100 years of operation [21]. It seems that the quoted part of opening speech of the iron bridge in 1878, stating that: [...] After 50 to 100 years old iron structures will begin to crack much earlier than we assume now [...], becomes a good prediction [7]. At present, in Poland, the age of railway bridges for almost half of them (Fig. 1) has reached the upper limit time for which they were designed [2]. Prof. Jan Bień of Wroclaw University of Technology defines that state by term: pathology and technical geriatrics of bridges [2]. 

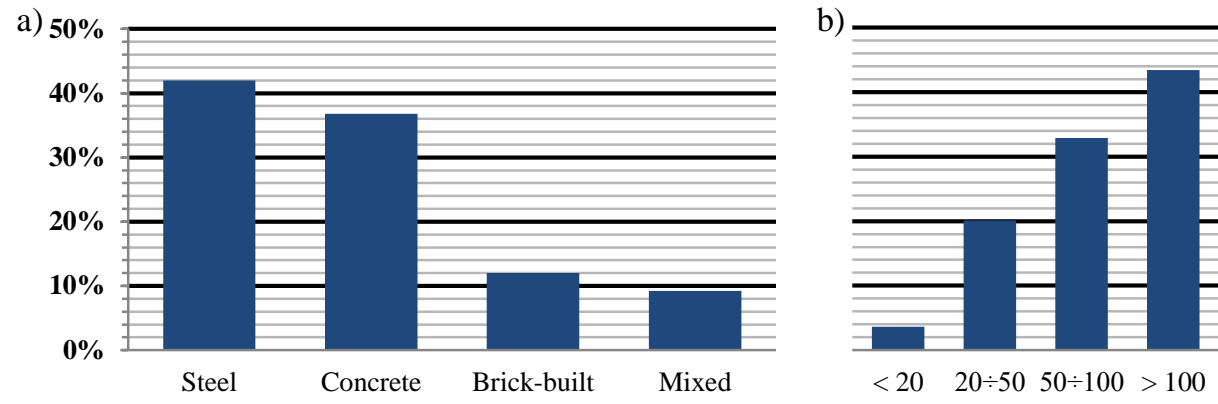

Fig. 1. Statistics of railway bridges in Poland; a) Construction material of bridge spans; b) Age in years. Based on: [2]

According to General Technical Specifications of the General Directorate of Public Roads, surveying methods (classical, photogram and satellite), which are used in bridge construction, serve not only to measurement of displacements and deformations, but also allow the spatial control of shape of the object and its components [26]. The stability of railway bridges, which is defined by surveying methods, is a fundamental tool in the diagnostics of railway infrastructure [2]. The technical condition of railway bridges in Poland consists in carrying out periodical technical inspections of structures. The main part of them is technical review, which is made by services of the railway lines. Their task is just visual review of the object. In addition, bridges are subject to (every 1 to 3 or 5 to 10 years) basic or extended review carried out by bridge inspectors or bridge diagnostics. Classical, surveying methods of testing the stability of bridge objects are carried out whenever the magnitude and tendency of a particular type of damage is required. In the acceptance tests and in static load tests, the basic classical surveying methods for measuring bridges are precise leveling, trigonometry and digital photogrammetry. The universal character of surveying methods for testing the stability of railway bridges provides indispensable information about the work of them. These measurements provide the basis for the diagnosis and prediction of the functioning of the infrastructure.

The need for industry to redefine the technical condition of railway infrastructure - at the time of high-speed rail development - has inspired authors to study the use of modern measurement technologies in determining the displacement and deformation of old, steel railway bridges. In the course of several years of research on the stability of the railway bridge, TLS (Terrestrial Laser Scanning) methodology was developed. The methodology was concerned with structural stability during periodic measurements and during static load test of bridge. The classical method of bridge stability (precise leveling and tachymetric measurement) was used in the methodology definition process as reference for TLS designations. The article presents compatibility of vertical displacements of 
steel railway bridge, which were developed in two classical measurement methods. The study is part of ongoing research and allows verification of the validity of the applied concept of measurement and development of classical data.

\section{OBJECT, SCHEDULE AND CONDITION OF RESEARCH}

Empirical research on the stability of old, steel railway bridge was carried out for the bridge in kilometer (sign. KM) 2.485 of railway line No. 098 Sucha Beskidzka - Chabówka. This railway bridge represents a population of steel structures of railway bridges, built in the $1960^{\mathrm{s}}$ of the last century. The construction of the railway bridge creates a double bridge span - continuous carrier structure with a theoretical length of bridge spans : $52.700 \mathrm{~m}+52.700 \mathrm{~m}=105.400 \mathrm{~m}$ (Fig. 2). According to PKP PLK S.A. contract, the facility manager of the bridge provided design and service documentation for research purposes. The content of archival materials contained mainly information about the reconstruction of the railway bridge and the characteristics of the designed load-bearing capacity of the structure. In addition, the analysis of the documentation showed that over the years the diagnostics of the railway bridge consisted only of periodic inspections, assessing the general condition of the structure. What is more, the static theoretical parameters of the over 50-year-old object are still in force, despite the fact that in the last decades there has been a revolution in rail transport, redefining the conditions of exploitation of the infrastructure.

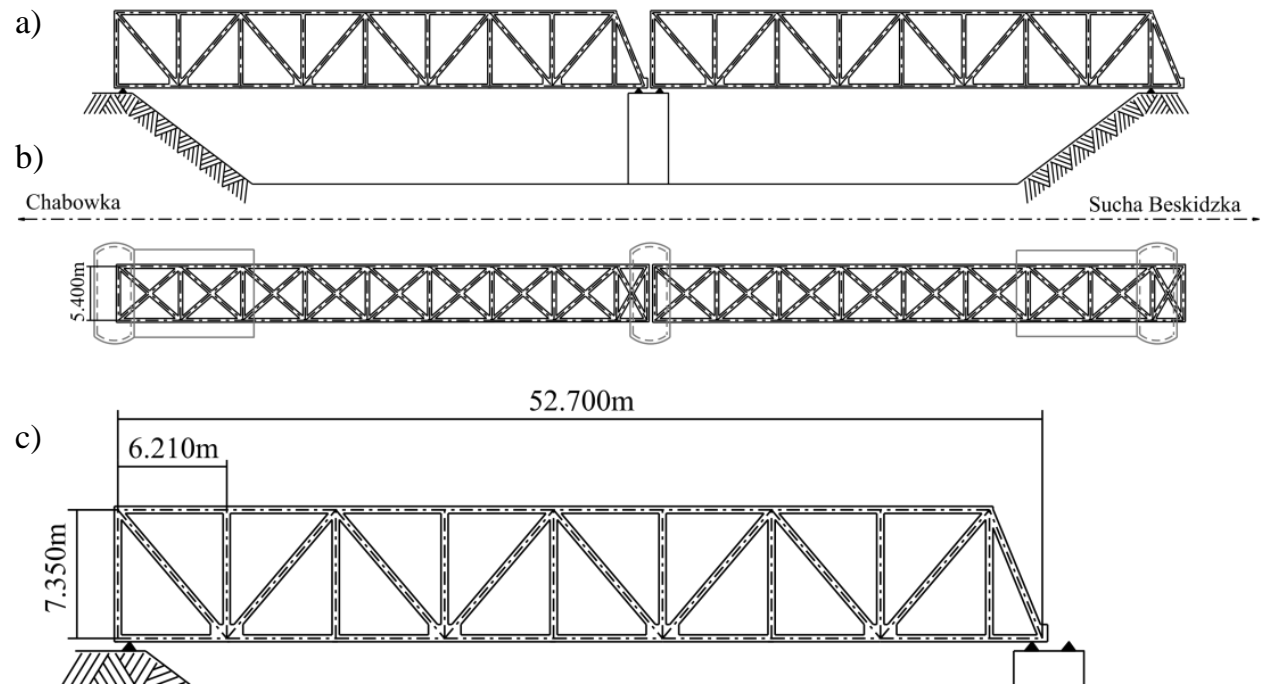

Fig. 2. Bridge geometry; a) Side view; B) Top view; c) Geometry of lattice bridge span 
The vertical displacements of railway bridge's girders, which were measured by classical methods, were carried out in the same way during periodic measurements and during static loads test (Tab. 1).

Table 1. Harmonogram pomiarów przemieszczeń mostu kolejowego

\begin{tabular}{|c|c|l|}
\hline $\begin{array}{c}\text { Measuring } \\
\text { series }\end{array}$ & May 2014 & $\begin{array}{l}\text { Periodic measurements of bridges, so-called zero } \\
\text { measurement }\end{array}$ \\
\hline $\mathbf{1}$ & October 2014 & Periodic measurements of bridges \\
\hline $\mathbf{2 a}$ & October 2014 & Measurements during static test loads \\
\hline $\mathbf{2 b}$ & July 2015 & Periodic measurements of bridges \\
\hline $\mathbf{3}$ &
\end{tabular}

Periodic measurements (one of the variants for monitoring geometric changes of an object [2]) were performed in a systematic way and allowed to track the dynamics of the construction [20]. The static load test of the railway bridge by the EN57 train was based on the putting $126.5 \mathrm{t}$ train van on the one of bridge span (Fig. 3). The exact location of the static load test scheme was established in consultation with the railway line diagnostics. According to commonly used load models, the static load test of multi-span railway bridges is often carried out for single bridge spans [15]. The local static load test of multi-span railway bridges allows to determine the dynamics of unevenly loaded construction directly during and after static load test.

a)

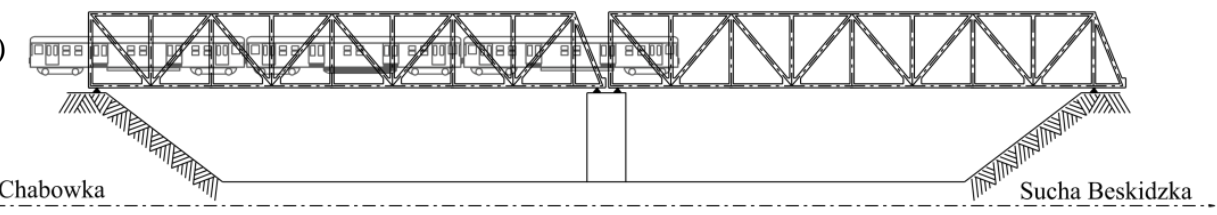

b)

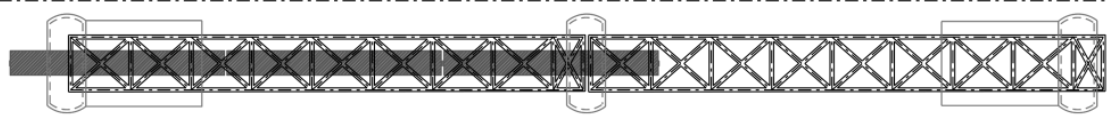

Fig. 3. Scheme of static load test of bridge span; a) Side view; b) Top view

Static load vibrations were generated during the static load test. These effect was muted in accordance with PN-S-10050: 1989 [25].

\section{METHODS OF CLASSICAL SURVEYING MEASUREMENTS}

The classical measurement procedure of vertical displacements of railway bridge was based on using the same measurement methods and the same class of surveying instrument. Each measurement method was implemented in every measuring epoch, at the same time; therefore, it represented the same condition of construction. 


\subsection{Geometric precise leveling}

Periodic precise leveling of the bridge spans was performed from two measurement stations, which were located outside the object (Fig. 4a). During the measurement the Leica NA3003 code leveler and Leica GPCL2 bar-code level rod were used. During testing, the point elements of the girders were measured. Their location overlapped with the construction node of bridge (Fig.4b). During precise leveling of the girder elements no turning plates were used for the barcode level rods. They were set directly on the point elements of the girders and their position was stabilized with the steel supports. Within the area of the railway bridge, there were three bench marks but only one $(R p)$ of them had credible information about height, accuracy and position. This bench mark was the tie point of precise leveling, during measurements and least square adjustment method. The other two bench marks $(R p 1, R p 2)$ were used in trigonometric leveling of controlled points.

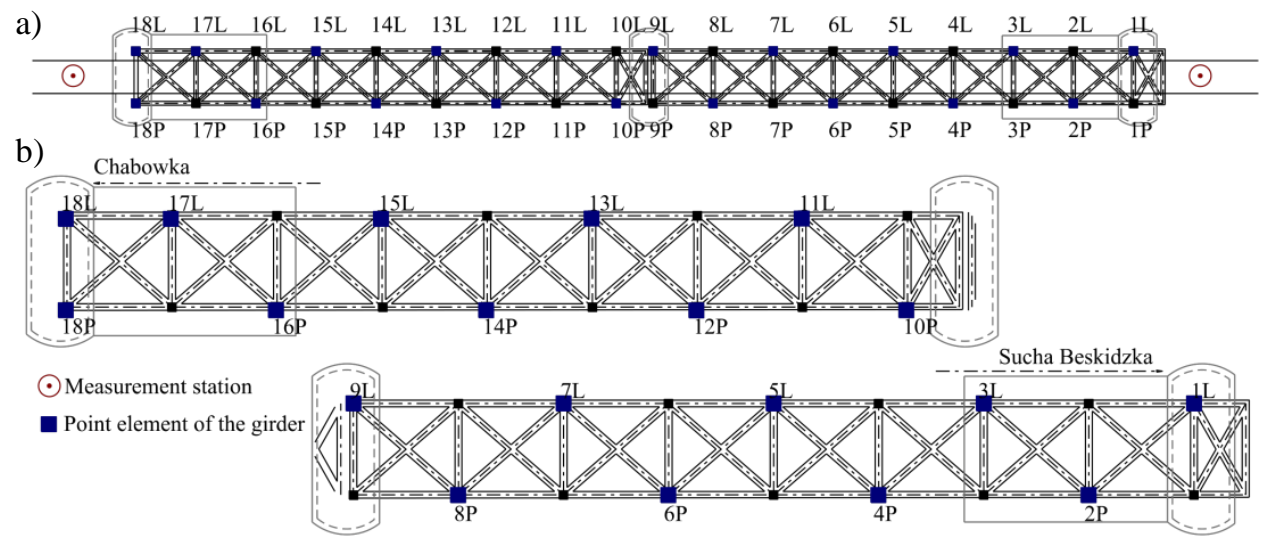

Fig. 4. Precise leveling of bridge spans a) Conception of placement of measurement stations and controlled points; b) Point elements of the girders, which were measured.

The precise leveling of the railway bridge represented the classical designations of the building mechanics. There was no need to do design and stabilization work during these measurements. The disadvantages of this method were: work at a height and work on the rail road.

\subsection{Precise trigonometric leveling}

Trigonometric leveling was done from single stations that were located directly above the points of horizontal and vertical network or were free stations (Fig. 5). Trigonometric leveling required design and stabilization work for controlled points. Their position in the vertical plane coincided with the points element girders which were leveled by precise leveling. The basic condition for the reliability of the results of trigonometric leveling measurement was the careful 
stabilization measurement station. Each of the measurement station was therefore tied to average five points of the horizontal and vertical network. The height of the controlled points (fixed to the object), determined by the trigonometric leveling method, obliged to the maximum possible reduction of measurement errors. As a result the height of horizontal axis of the precise tachymeter was leveled. For this purpose, two bench marks (Rp1, Rp2) were used. They were located on the bridge area but were not characterized in the documentation of the bridge. Determining their heights and examining their vertical stability was carried out during the periodic research on the stability of the points of horizontal and vertical networks.

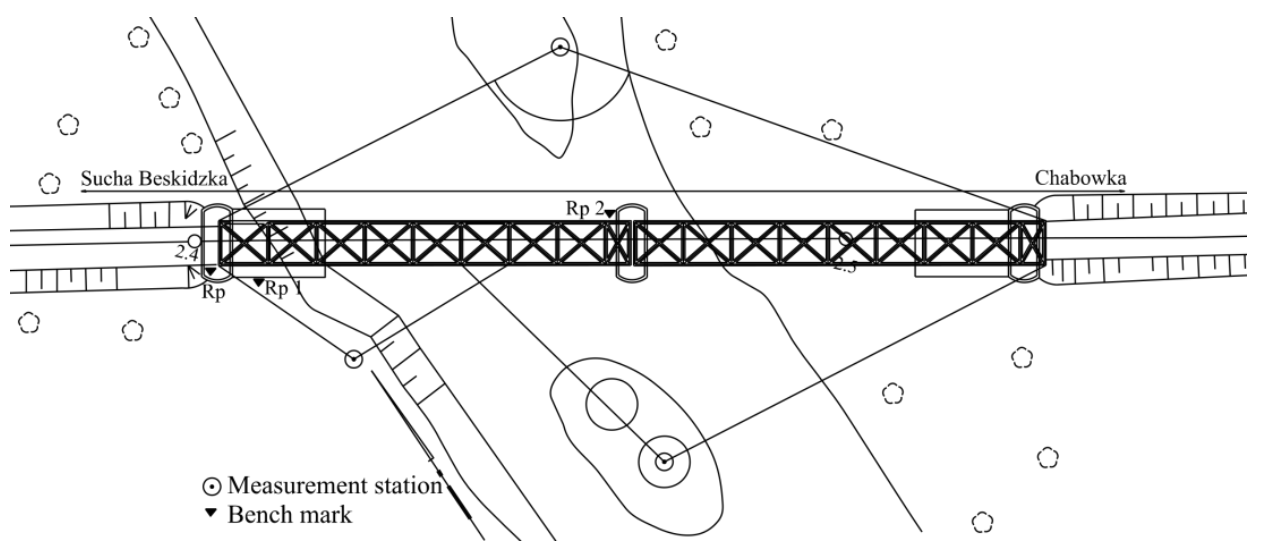

Fig. 5. Conception of placement of measurement stations and controlled points in trigonometric leveling

Controlled points were measured by robotic total stations, which have precise parameters of electrooptical stadias (Trimble VX, Trimble 5602 DR200 Plus). Thanks to it, the accuracy of the height of the points of controlled network allowed to an analysis of their displacement.

Based on general assumption, the accuracy obtained in classical trigonometric leveling does not measure up to precise leveling. Still, their application was decided by organizational considerations (safety, measurement time, remote measurement).

\section{THE VERIFICATION PROCEDURE OF COMPATIBILITY OF VERTICAL DISPLACEMENT (ACHIEVED BY CLASSICAL LAND SURVEYING MEASUREMENT)}

The verification procedure of compatibility of vertical displacement was based in three steps of solution. 
The first step was the calculation of results of levelings by the least square method, which were measured in periodic measurement series. This study was made in GEONET software.

The second step was the determination of vertical displacement of bridge elements in epoch measurements: 1-2a, 1-3, 2a-2b. The determination of vertical displacement of bridge elements was done in GEONET software. During study the researchers used an application that is dedicated to adjustment and analysis of vertical displacement. The vertical displacement of point elements of the girders (sign. LEV) were calculated based on adjusted precise leveling data. During the analysis, an absolute reference system was adopted which contained the $R p$ bench mark. In the same way vertical displacement of controlled points (sign. TRYG), (which were measured by trigonometric leveling) was calculated. During the analysis, an absolute reference system was adopted which contained points of horizontal and vertical network.

The third step was made the statistical test of compatibility of displacement results, which were calculated in two different classical way.

To test whether two underlying one-dimensional probability distributions differ of the two sets of displacement Two-sample Kolmogorov-Smirnov test (sign. K-S) was carried out. The K-S test allowed to compare empirical distribution functions of the first and the second sample, for which the sizes of them is lower than during using t-Student test. The K-S test, which is popular used in civil engineering, is a good statistic for testing the compatibility of displacements. It is not only sensitive to differences in both location of the empirical cumulative distribution functions of the two samples, but also to their shapes [11].

To verify the compatibility of displacement (which were calculated in two different classical way: precise leveling (sign. LEV) and precise trigonometric leveling (sign. TRYG)) of the same point elements of girders, the authors

\section{verified}

Null hypothesis:

$H_{0}: F_{1}(L E V)=F_{2}(T R Y G)$ : The empirical distribution functions of the first and the second sample respectively are identical.

\section{Alternative hypothesis:}

$H_{1}: F_{1}(L E V) \neq F_{2}(T R Y G):$ The empirical distribution functions of the first and the second sample respectively are not identical.

During statistic tests, significance level $(\alpha)$ (a probability threshold below which the null hypothesis will be rejected) had value $1 \%$. The cluster analysis of the first 
and the second sample were made with size of one cluster which was equal accuracy of trigonometric leveling. This solution is in accordance with the principle that the size of one cluster should not be greater than the unit adopted for a defined scale problem [17].

\section{RESULTS AND DISCUSSION}

Results of periodic precise leveling of bridge spans presented high accuracy and high relative reliability of measurements (Tab. 2). The largest, average standard deviation of height was equal $\pm 0.61 \mathrm{~mm}$.

Table 2. Results of precise leveling data after calculation by the least square method

\begin{tabular}{|c|c|c|c|}
\hline \multirow{2}{*}{$\begin{array}{c}\text { Measuring } \\
\text { series }\end{array}$} & \multicolumn{2}{|c|}{ Standard deviation of height } & $\begin{array}{c}\text { Relative reliability } \\
\text { factor }\end{array}$ \\
\cline { 2 - 3 } & Average & Maksimum & $\mathbf{z}[\%]$ \\
\hline $\mathbf{1}$ & $\mathbf{m H}[\mathbf{m m}]$ & $\mathbf{m H m a x}[\mathbf{m m}]$ & 52.50 \\
\hline $\mathbf{2 a}$ & 0.61 & 0.79 & 52.50 \\
\hline $\mathbf{2 b}$ & 0.24 & 0.31 & 55.00 \\
\hline $\mathbf{3}$ & 0.33 & 0.44 & 52.38 \\
\hline
\end{tabular}

The high accuracy of measurements was also obtained in the process of calculation of trigonometric leveling data (Tab. 2). The largest, average standard deviation of height was equal $\pm 0.72 \mathrm{~mm}$. The high accuracy of the trigonometric leveling was the result of the measurement procedure, particularly the leveling of the horizontal axis of the tachymeter.

Table 3. Results of trigonometric leveling data after calculation by the least square method

\begin{tabular}{|c|c|c|c|}
\hline \multirow{2}{*}{$\begin{array}{c}\text { Measuring } \\
\text { series }\end{array}$} & \multicolumn{2}{|c|}{ Standard deviation of height } & \multirow{2}{*}{$\begin{array}{c}\text { Relative reliability } \\
\text { factor }\end{array}$} \\
\cline { 2 - 3 } & Average & Maksimum & $\mathbf{z}[\%]$ \\
\hline $\mathbf{1}$ & $\mathbf{m H}[\mathbf{m m}]$ & $\mathbf{m H m a x}[\mathbf{m m}]$ & 62.60 \\
\hline $\mathbf{2 a}$ & 0.72 & 0.79 & 54.30 \\
\hline $\mathbf{2 b}$ & 0.74 & 0.81 & 56.00 \\
\hline $\mathbf{3}$ & 0.73 & 0.84 & 53.30 \\
\hline
\end{tabular}

The results of leveling measurement of bridge spans were used to calculation of vertical displacement of object in period of series: 1-2a, 2a-3 and during static load test (2a-2b). Vertical displacements, which were obtained by classical methods (precise leveling, sign. LEV; and trigonometric leveling, sign. TRYG) were two samples for which the distribution identity statistics were distributed by the K-S test. Statistical tests for periodic, vertical displacement (1-2a, 1-3) have shown that the samples belong to the same population (Tab. 4, Tab. 5). Apart from 
the statistic value $(\lambda)$, the identity of periodic distributions of two samples has been confirmed by the distribution graphs.

Table 4. Results of Two-sample K-S test; Period 1 - 2a; $\left(n_{1}, n_{2}, \alpha\right)=(18,18,0.01)$

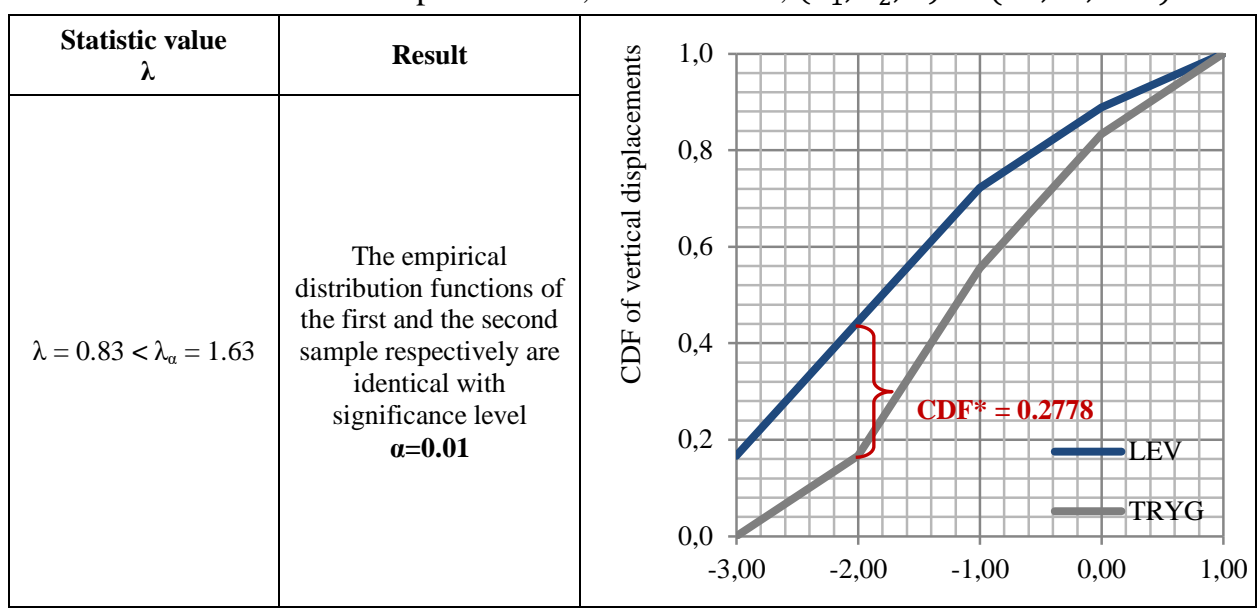

*CDF - Cumulative Distribution Function

Table 5. Results of Two-sample K-S test; Period $1-3 ;\left(n_{1}, n_{2}, \alpha\right)=(18,18,0.01)$

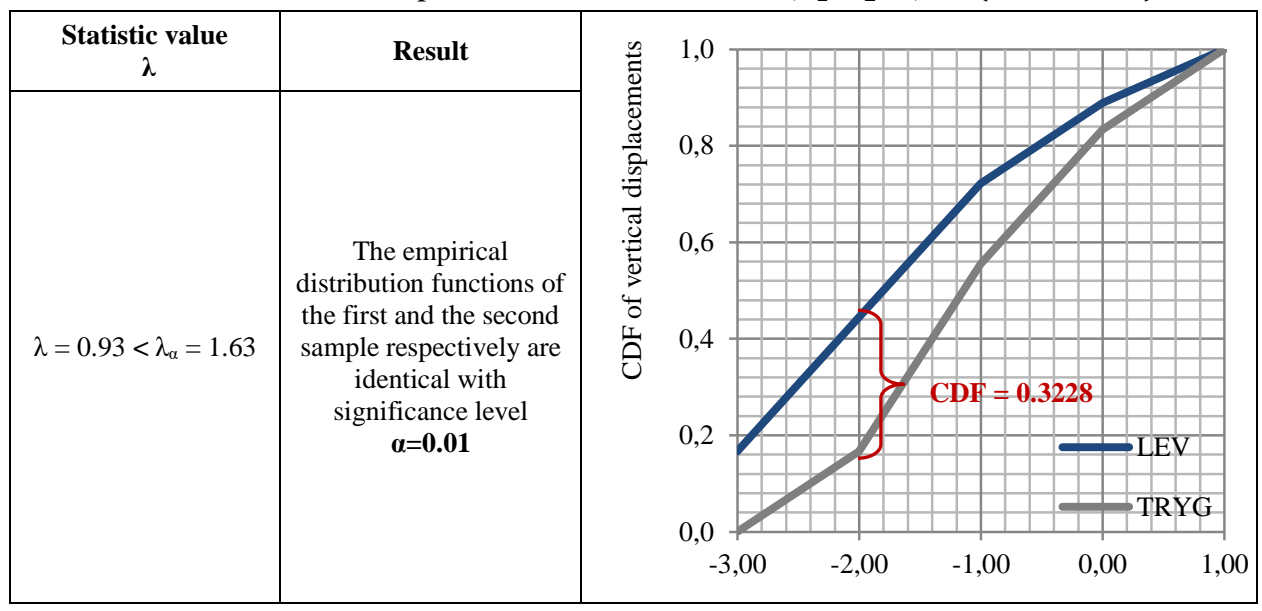

In conclusion, there is $99 \%$ probability that periodic vertical displacements of a railway bridge (which were obtained by two classical methods) are similar to each other in terms of descriptive statistics. As a result, they represent the same vertical trend of periodic displacement of the construction.

In addition, the point compatibility of vertical displacements of bridge was confirmed by percentage analysis of vertical displacement differences (Tab. 6). It follows that on average $40 \%$ of the periodic vertical displacements, which were 
obtained by trigonometric leveling differed less than $1.00 \mathrm{~mm}$ from the precision leveling one.

Table 6. Percentage analysis of vertical displacement differences; a) Period 1 - 2a, b)

\section{Period 1-3}

a)

\begin{tabular}{|c|c|}
\hline $\begin{array}{c}\text { The value of } \\
\text { displacement } \\
\text { difference } \\
\text { LEV/TRYG }[\mathrm{mm}]\end{array}$ & $\begin{array}{c}\text { \% } \\
\text { of all }\end{array}$ \\
\hline $0-0.5$ & 21 \\
\hline $0.5-1.0$ & 16 \\
\hline $1.0-1.5$ & 11 \\
\hline $1.5-2.0$ & 5 \\
\hline $2.0-2.5$ & 32 \\
\hline $2.5<$ & 16 \\
\hline
\end{tabular}

b)

\begin{tabular}{|c|c|}
\hline $\begin{array}{c}\text { The value of } \\
\text { displacement } \\
\text { difference } \\
\text { LEV/TRYG }[\mathrm{mm}]\end{array}$ & $\begin{array}{c}\text { \% } \\
\text { of all }\end{array}$ \\
\hline $0-0.5$ & 33 \\
\hline $0.5-1.0$ & 33 \\
\hline $1.0-1.5$ & 7 \\
\hline $1.5-2.0$ & 7 \\
\hline $2.0-2.5$ & 20 \\
\hline $2.5<$ & 0 \\
\hline
\end{tabular}

Table 7. Results of Two-sample K-S test; Static load test (Period 2a-2b), $\left(n_{1}, n_{2}, \alpha\right)=$ $(17,17,0.01)$

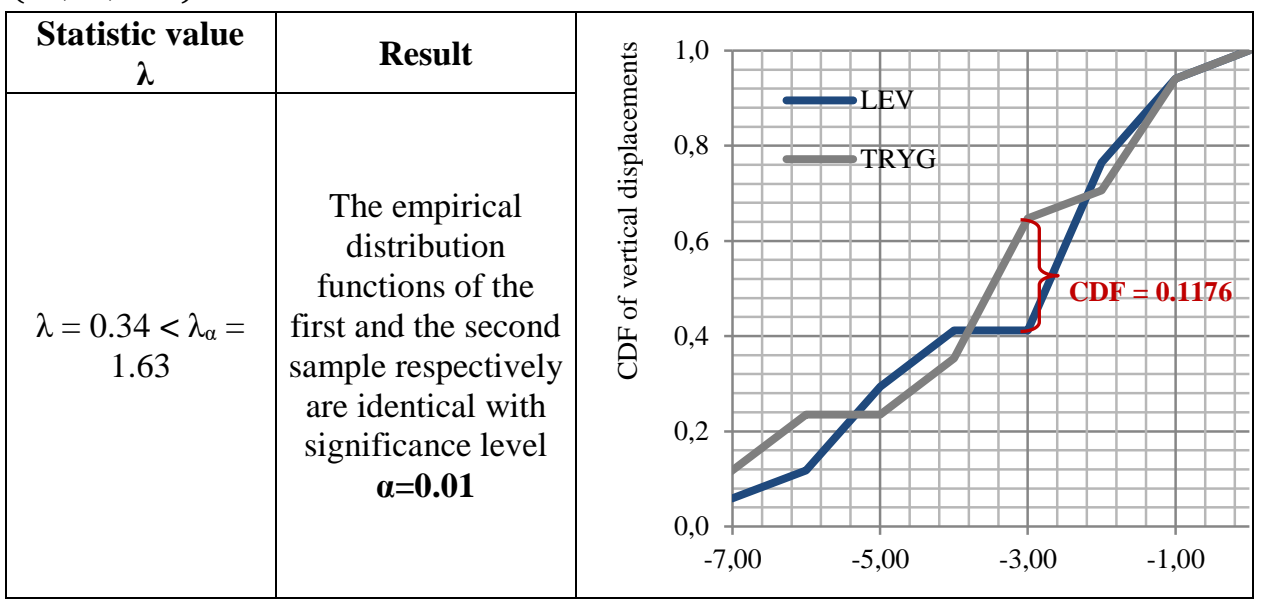

The same statistical analysis was done for vertical displacements during static load test. The value of statistics $(\lambda)$ and distribution graphs shown that the empirical distribution functions of the first and the second sample respectively are identical. In addition, the point compatibility of vertical displacements of bridge was confirmed by percentage analysis of vertical displacement differences (Tab. 7) 
Table 6. Percentage analysis of vertical displacement differences; Static load test (Period $2 a-2 b)$

\begin{tabular}{|c|c|}
\hline $\begin{array}{c}\text { The value of displacement difference } \\
\text { LEV/TRYG [mm] }\end{array}$ & $\begin{array}{c}\text { \% } \\
\text { of all }\end{array}$ \\
\hline $0-0.5$ & 12 \\
\hline $0.5-1.0$ & 12 \\
\hline $1.0-1.5$ & 29 \\
\hline $1.5-2.0$ & 18 \\
\hline $2.0-2.5$ & 12 \\
\hline $2.5<$ & 18 \\
\hline
\end{tabular}

The use of precise leveling in the study of bridge stability (not just railway bridge) is one of the most common research solution. The need for this classical method of measuring vertical displacement is confirmed by, inter alios, static load tests of the Warsaw Bridge in Wroclaw [1], the railway viaduct WK-3 of railway line No 25 Łódź Kaliska - Dębica [15] or the railway bridge in Wrocław on the E59 railway [16]. An example of the application of precise leveling as a part of stability study in the context of measurements, which verify the design assumptions of age objects can be found in the research work on: railway bridge over Przemsza on railway line No.180 Dorota - Jęzor - Brzezinka [18], border bridge in Cieszyn [19] or bridge over the Vistula river in Pulawy, within the national road no.12 Radom - Lublin [3].

In the era of modern measuring technologies, including precise reflectorless tachymetry, the trigonometric leveling becomes more and more competitive for precise leveling. The presented studies indicate that proper preparation of the research object (controlled network points) and the appropriate measurement procedure allow to determine the stability of old structure - especially valuable in the case of load tests. The potential of trigonometric leveling in measurements of displacement is confirmed by, inter alios, static and dynamic load tests of bridge in Zembrzyce (Voivodship Road No. 956) [6]; the 400-meter-long bridge in Verona [24] or the road transport bridges on the route Koper - Krško in Slovenia [9].

\section{CONCLUSION}

Measurements of changes of the structure in the vertical plane allowed to show the dynamics of the work of the bridge. These studies give the construction industry a basis for the interpretation of construction behaviour under the influence of naturogenic and technogenic factors. Age railway infrastructure, in the era of high-speed rail development, need to redefine their technical parameters. The use of classical surveying methods to determine the vertical 
displacements of the railway bridge shown that the trigonometric leveling method, which is characterized by the ability to remote and speed measure shows the tendency of movement of the structure according to the precise leveling results. Obligatory elements of the concept of measurement of bridge constructions in the classical method of trigonometric are:

- leveling of the horizontal axis of the tachymeter,

- using of precise reflector and reflectorless total station,

- appropriate number of measurement series.

\section{ADDITIONAL INFORMATION}

The presented results of the analyzes are part of the studies on the determining of the methodology of the survey of stability of bridged objects using terrestrial laser scanning, which is the content of the finalized but not published dissertation [5].

\section{REFERENCES}

1. Bień J., Banakiewicz A, Rawa P., Zwolski J., Adamcewicz S. 2008a. Badania wschodniej konstrukcji nowego mostu Warszawskiego we Wrocławiu. Wrocławskie dni mostowe: Mosty stalowe. Projektowanie, technologie budowy, badania, utrzymanie. Wrocław. 27-28 listopada 2008.

2. Bień J. Uszkodzenia i diagnostyka obiektów mostowych. Wydawnictwa Komunikacji i Łączności. Warszawa. 2010.

3. Chróścielewski J., Malinowski M., Miśkiewicz M. 2008. Próbne obciażenia mostu przez Wistę w Pulawach. Wrocławskie dni mostowe. Mosty stalowe. Projektowanie, technologie budowy, badania, utrzymanie. Wrocław, 27-28 listopada 2008.

4. Duffy M.A., Hill CH., Whitaker C., Chrzanowski A., Lutes J., Bastin G. 2001. An automated and integrated monitoring program for Diamond Valley Lake in California. Proceedings of the 10th FIG Symposium on Deformation Measurements, 19-22 March 2001, Orange, California USA.

5. Gawronek P. Metodyka badania stabilności obiektów mostowych z zastosowaniem naziemnego skaningu laserowego. Rozprawa doktorska. Uniwersytet Rolniczy w Krakowie. Kraków, 2017.

6. Gocał J., Ortyl Ł., Owerko T., Kuras P., Kocierz R., Ćwiąkała P., Puniach E., Sukta O., Bałut A. Determination of displacements and vibrations of engineering structures using ground-based interferometry. Wydawnictwa AGH. 2013. Kraków.

7. IABSE Symposium Washington DC, Maintenance, Repair and Rehabilitation of Bridges, Vol. 38, 1982. 
8. Kamiński W. 2007. Niwelacja trygonometryczna $i$ niwelacja techniczna w wyznaczaniu wysokości punktów. Przegląd geodezyjny. Rok LXXIX. Nr 8.

9. Kamnik R., Kovačič B., Štrukelj A. 2010. Deformation Analysis of bridges in exceptional transports in Slovenia. Promet - Traffic\&Transportation, Vol. 22, 2010, No. 1: 15 - 22.

10. Klasztorny M. Dynamika mostów belkowych obciażonych pociagami szybkobieżnymi. Wydawnictwa Naukowo-Techniczne. Warszawa. 2005.

11. Krysicki W., Bartos J., Dyczka W., Królikowska K., Wasilewski M. Rachunek prawdopodobieństwa $i$ statystyka matematyczna $w$ zadaniach. Część II. Statystyka matematyczna. Wydanie IV. Wydawnictwo Naukowe PWN. Warszawa, 1999.

12. Kużawa M. J., Cruz P. J. S., Bień J. 2008. Analysis and fatigue evaluation of Pinhao bridge in Portugal. Mosty stalowe: projektowanie, technologie budowy, badania, utrzymanie. Seminarium, Wrocław, 27-28 listopada 2008. Dolnośląskie Wydawnictwo Edukacyjne: 207 - 218.

13. Lazzarini T. Geodezyjne pomiary przemieszczeń budowli i otoczenia. PPKW. Warszawa. 1977.

14. Leica Geosystems AG. General Notice. Digital levels NA2002/NA3003 V3.3. Switzerland. 1997.

15. Łaziński P., Pradelok S. Badanie odbiorcze wieloprzęstowego wiaduktu kolejowego nasuwanego poprzecznie. Wrocławskie dni mostowe: Obiekty mostowe w infrastrukturze miejskiej. Wrocław. 21 - 22 listopada 2013.

16. Łaziński P., Salamak M., Owerko T. 2015. Próbne obciążenia mostów w Polsce na podstawie wybranych przykładów. VII Ogólnopolska Konferencja Mostowców - Konstrukcja i Wyposażenie Mostów. Wisła, 28 29 maja, 2015.

17. Plucińska A., Pluciński E. Probabilistyka. Wydawnictwo Naukowo Techniczne. Warszawa, 2000.

18. Pradelok S.. Będkowski P. 2007. Naprawa i próbne obciążenie kratowego mostu kolejowego. XXIII Konferencja Naukowo - Techniczna, Szczecin Międzyzdroje. 23 - 26 maja 2007.

19. Salamak M., Łaziński P., Pradelok S., Będkowski P. 2014. Badania odbiorcze mostów kolejowych pod próbnym obciążeniem dynamicznym - wymagania i praktyka. Konferencja Naukowo-Techniczna INFRASZYN 2014. Projektowanie, budowa i utrzymanie Infrastruktury w transporcie szynowym.

20. Składowski M. 2009. Współczesny monitoring obiektów budowlanych. Przegląd Budowlany. nr 3: 37 - 46.

21. Szadkowski K. 2015. Mosty kolejowe - przeglad inwestycji. Konferencja: Forum budowy i utrzymania obiektów inżynieryjnych Mosty 2015. Wieliczka, 24. czerwca 2015 r. 
22. Taylor W. 2013. Iron, Engineering and Architectural History in Crisis: Following the Case of the River Dee Bridge Disaster, 1847. Architectural Histories, 1(1): 23: 1 - 13.

23. Toś C.. Wolski B.. Zielina L. 2010. Zastosowanie tachimetru skanujacego w praktyce geodezyjnej. Środowisko. Czasopismo techniczne. Zeszyt 16. 1 Ś/2010.

24. Zordan T., Briseghella B., Lan Ch. 2011. Parametric and pushover analyses on integral abutment bridge. Engineering Structures 33: 502 - 515.

25. PN-S-10050:1989 Obiekty mostowe - Konstrukcje stalowe - Wymagania i badania

26. Pomiary przemieszczeń i odkształceń obiektów mostowych metodami geodezyjnymi, Ogólne Specyfikacje Techniczne, GG -00.13.01. Generalna Dyrekcja Dróg Publicznych. Warszawa. 1998.

\section{ZASTOSOWANIE KLASYCZNYCH METOD GEODEZYJNYCH DO WYZNACZANIA PRZEMIESZCZEŃ PIONOWYCH BELEK DŹWIGARA MOSTU KOLEJOWEGO}

\section{Streszczenie}

Pomiary klasyczne stabilności mostu kolejowego, w kontekście wyznaczania przemieszczeń pionowych dolnych belek konstrukcyjnych obiektu, polegały na niwelacji precyzyjnej wpustów dźwigarów oraz niwelacji trygonometrycznej punktów kontrolowanych, zamocowanych do konstrukcji mostu w płaszczyznach pionowych niwelowanych wypustów. Pomiary wysokościowe metodami klasycznymi realizowano podczas okresowego badania stabilności konstrukcji oraz podczas próbnych obciążeń statycznych mostu taborem kolejowym. Specyfika pomiarów przemieszczeń, rodzaju obiektu podlegającego pomiarowi oraz warunków pracy w geodezji kolejowej zobligowała do zdefiniowania metodyk pomiarów wysokościowych, zapewniających pozyskanie danych o zadowalającym stopniu dokładności oraz niezawodności w kontekście badanego zjawiska. W artykule dokonano oceny stopnia zgodności wyznaczonych przemieszczeń pionowych pozyskanych na podstawie precyzyjnej niwelacji geometrycznej oraz niwelacji trygonometrycznej. W podsumowaniu zaproponowano optymalną pod względem dokładności, ekonomii pomiaru oraz bezpieczeństwa koncepcję wyznaczania przemieszczeń pionowych dolnych belek dźwigara mostu kolejowego z zastosowaniem metody klasycznej.

Słowa kluczowe: Przemieszczenia i odkształcenia obiektu, niwelacja precyzyjna, niwelacja trygonometryczna, stalowy most kolejowy

Editor received the manuscript: 31.12 .2017 